\title{
A Cultura Humanitária Contestada em Zonas de Guerra*
}

Thomas G. Weiss**

A ação humanitária em zonas de guerra nunca foi fácil, porém tem se mostrado especialmente intimidadora no pós-Guerra Fria. Embora nunca tenha existido uma era de ouro, David Rieff (2002b) e outros lamentam, nostalgicamente, o atual "humanitarismo em crise". Esta, no entanto, dificilmente se mostra uma crise de "meia-idade", visto que muitos observadores (FORSYTHE, 2005; BARNETT, 2011) datam seu nascimento já da criação, em meados do século

\footnotetext{
* Artigo submetido para publicação em 21 de agosto de 2014 e aprovado em 3 de setembro de 2014. Este artigo é a primeira versão do texto "Humanitarianism's Contested Culture in War Zones", a ser publicado em Humanitarianism and Cultures of Cooperation, editado por Tobias Diebel, Dirk Messner e Claus Leggewie (Londres: Routledge, 2015). Artigo traduzido por Victor Coutinho Lage. E-mail: victorcoutinholage @yahoo.com.br.

** Presidential professor do Graduate Center da City University of New York, diretor emérito do Ralph Bunche Institute for International Studies e professor pesquisador do SOAS, University of London. Já foi diretor de pesquisa do International Commission on Intervention and State Sovereignty. Entre seus recentes livros relevantes para o tema deste artigo, estão Humanitarian Business (2013), Humanitarian Intervention: Ideas in Action (2012) e Humanitarianism Contested: Where Angels Fear to Tread (2011). Dois livros recentemente editados também se relacionam com o tema: The International Politics of Human Rights: Rallying to the R2P Cause? (2014) e The Responsibility to Protect: Cultural Perspectives in the Global South (2011). E-mail: tweiss@gc.cuny.edu.
}

CONTEXTO INTERNACIONAL Rio de Janeiro, vol. 36, nº 2, julho/dezembro 2014, p. 305-348. 
XIX, do Comitê Internacional da Cruz Vermelha (CICV). Não importando a época à qual se retorne e a despeito de Steven Pinker (2011), os humanitaristas não estão mais necessariamente do lado dos anjos - suas motivações e a profundidade de seu conhecimento, seus princípios e resultados são questionados por dentro e por fora.

O entendimento das transformações em curso no humanitarismo contemporâneo requer o exame da natureza e da evolução da cultura humanitária - seus valores, linguagem, comportamento. Este ensaio começa com a cultura tradicional dominante, que servirá de parâmetro para se explorar o afastamento de uma cultura acordada de cooperação, em direção a uma cultura contestada de competição, fruto da militarização, da politização e da mercantilização. Conclui-se com um apelo por uma "cultura de aprendizagem", orientada para a reflexão responsável, ao invés de ser orientada para a reação rápida.

\section{A Cultura Dominante, 0 Bom Samaritano}

A palavra "humanitarismo" está enraizada em dimensões de moralidade e princípio - a parábola do "Bom Samaritano" em geral vem à mente. O objetivo é nobre, ajudar populações vulneráveis, independente de quem sejam, de onde estejam ou do porquê de suas necessidades. Agências de ajuda estão interessadas no bem-estar dos que estão sob seus cuidados e não são afetadas por fatores políticos e de mercado dos países que proveem ou que recebem assistência. A ação humanitária consiste no provimento de alívio emergencial para o salvamento das vidas de pessoas ameaçadas e na proteção dos direitos humanos fundamentais dessas pessoas. Ambas as tarefas objetivam incorporar à rede global de segurança os indivíduos presos no turbilhão dos desastres produzidos pelos seres humanos. Supostamente, as duas tarefas se reforçam de maneira mútua, embora muitos humanitaristas se especializem e tentem isolar uma da outra, visto que, ao 
tornar o socorro à vida uma meta subordinada, o alívio emergencial torna-se refém dos direitos humanos.

A própria palavra "humanitarismo" possui ressonância, porém é vã a busca por uma definição inequívoca. Na ocasião da disputa entre Nicarágua e Estados Unidos, a Corte Internacional de Justiça (CIJ) foi evasiva, afirmando que a ação humanitária é aquilo que o CICV faz por inferência, a provisão independente, neutra e imparcial de alívio a vítimas de conflitos armados e desastres naturais.

O Oxford English Dictionary - cuja edição de 1819 cita a palavra pela primeira vez - lança mão de tautologias: humanitarismo significa "ter estima pelos interesses da humanidade e da espécie humana com um todo; relacionando-se, advogando em favor ou praticando a humanidade ou a ação humana". No discurso corrente, o humanitarismo (substantivo) consiste em ações que aprimorem o bem-estar; humanitário (substantivo) é aquele que promove ativamente tais aprimoramentos; e humanitário (adjetivo), em geral, significa filantropo ou caridoso.

A definição da CIJ requer a análise do padrão de ouro do CICV. A política de ajuda na ocasião de um desastre natural é relativamente simples, tendo em vista que todo país, não importa o quão sofisticado, pode acabar sofrendo um desastre semelhante ao tsunami de 2011 e ao acidente nuclear de Fukushima, e que seria peculiar a recusa de ajuda externa nesses casos. Contudo, solicitar ajuda em meio a guerras é uma questão diferente, muito mais preocupante. Os governos em meio às convulsões de um conflito armado - principalmente em guerras civis - com frequência entendem a ajuda como um nítido indicativo de fraqueza. Além disso, ajuda e proteção representam recursos fungíveis que são parte dos cálculos para se vencer uma guerra; com isso, os beligerantes não são avessos à manipulação da assistência e das vidas civis como parte de seu arsenal no conflito. 
O CICV ocupa uma posição incomum, sendo amiúde tratada como sui generis. A Cruz Vermelha é a organização internacional humanitária mais velha, além de ser a maior fora do Sistema ONU (Organização das Nações Unidas). Uma organização privada, com uma assembleia formada por proeminentes cidadãos suíços, o CICV assemelha-se a organizações não governamentais (ONGs), na medida em que recebe contribuições tanto privadas quanto públicas. Entretanto, os governos proveem $90 \%$ de seu orçamento anual, em torno de 1,2 bilhão de dólares, para cobrir os gastos de 11 mil funcionários em oitenta países. Além disso, a organização é uma categoria por si só, dado que custodia as Convenções de Genebra - é um híbrido, não sendo nem uma organização intergovernamental (OI) nem uma ONG.

Ao contrário da maior parte das agências humanitárias, o CICV elaborou princípios, e seu disciplinado corpo de funcionários é comprometido a respeitá-los - no papel, sempre; na realidade, frequentemente. Ao contrário da maior parte das ONGs e das OIs, que levam a cabo uma gama de atividades que vai do alívio à reconstrução e ao desenvolvimento, o CICV opera apenas nas zonas de guerra. Suas regras de base focam-se no que o humanitarismo deve supostamente fazer e em como deve fazê-lo. Em seu famoso desiderato, Jean Pictet (1979) identificou sete princípios definidores: humanidade, imparcialidade, neutralidade, independência, serviço voluntário, unidade e universalidade. ${ }^{1}$

É plausível dizer que os primeiros quatro princípios constituem o núcleo. O princípio da humanidade (ou dignidade humana) é inconteste e comanda a atenção de todos os demais, ao passo que os outros três são discutíveis e debatidos. Imparcialidade requer que a assistência seja baseada na necessidade e não discrimine com base em nacionalidade, raça, religião, gênero ou afiliação política. Neutralidade demanda que as organizações humanitárias se abstenham de tomar parte em hostilidades ou em qualquer ação que beneficie ou gere desvantagens aos beligerantes. Independência requer que a assistência 
não se conecte a qualquer parte interessada no resultado de uma guerra; dessa forma, há uma regra geral de se rejeitar ou se limitar a dependência do financiamento de governos que tenham interesses envolvidos nesse resultado.

O CICV derivou esses princípios de décadas de experiência prática com aquilo que funciona melhor. Embora muitos observadores os tratem hoje como sacrossantos - sendo, a rigor, a essência da cultura humanitária -, tais princípios começaram como julgamentos pragmáticos. Em termos simples, princípios tradicionais ajudaram a guiar humanitaristas na busca por se chegar às pessoas sob pressão resultante de conflitos internacionais e desastres naturais. Caso as agências de ajuda sejam percebidas pelos combatentes como aliadas do lado oposto ou portadoras de um interesse investido na situação, elas passam a enfrentar dificuldades de acesso, podendo até mesmo se tornar alvos. Caso os princípios sejam religiosamente respeitados, argumenta-se, tanto os assistentes envolvidos na ajuda quanto seus receptores se beneficiam de proteção. Operar de acordo com tais princípios e ser percebido como apolítico têm sido crucial durante as guerras.

Em suma, a cultura do humanitarismo reflete o desejo e a habilidade de se prover uma assistência que salve vidas, ao mesmo tempo em que honra a neutralidade, a imparcialidade e a independência. No entanto, quão pertinente é essa tradição em sociedades atuais devastadas pela guerra? É virtualmente impossível permanecer acima das lutas e respeitar os princípios, face à militarização, à politização e à mercantilização desenfreadas. A questionável relevância da cultura humanitária tradicional em muitos contextos contemporâneos demanda que revisitemos seu impacto nos "princípios" ou "procedimentos" operacionais padrão (POPs) do humanitarismo.

\section{Militarização}

O envolvimento rotineiro de forças militares terceiras em esforços humanitários é um fenômeno notável do pós-Guerra Fria - em espe- 
cial na África, onde estão empregados três quartos da forças da ONU ou autorizadas pela ONU (CENTER ON INTERNATIONAL COOPERATION, 2013; ADEBAJO, 2011). Contudo, o uso de forças militares para tais propósitos não é algo novo, haja vista que uma significativa expansão ocorreu depois da Segunda Guerra Mundial, quando as ocupações da Alemanha e do Japão, assim como a reconstrução de suas economias, demandaram novos tipos de pessoal no interior das Forças Armadas: administradores, planejadores e especialistas em logística. Os militares amiúde possuem em abundância os recursos cuja oferta é a menor quando um desastre ocorre: transporte, combustível, linhas de comunicação, commodities, equipamento de construção, medicamentos e mantimentos. Eles ainda apresentam alguns elementos que são vantajosos em meio a um tumulto catastrófico: a mentalidade do "podemos fazer", o caráter de autoapoio, as capacidades de resposta rápida e a disciplina hierárquica. De modo mais decisivo, os militares podem gerar benefícios humanitários, devido ao exercício direto de suas funções primárias de combate em guerra e à sua força superior para sobrepujar forças hostis. O desempenho de tais funções deve ser distinguido do que se faz após desastres naturais ou em conjunto com mantenedores da paz (peacekeepers) tradicionais. Os humanitaristas militares são capazes de obter acesso aos civis em condição de sofrimento, quando a insegurança torna isso impossível ou altamente perigoso; e podem criar um ambiente suficientemente seguro para permitir o socorro e a proteção por outros. Tais interventores ainda podem mudar o regime responsável pelo sofrimento, admitidamente um resultado mais contestado de seus esforços.

A militarização tem se mostrado problemática para os humanitaristas, e críticos têm sido severos em relação à função de segurança. Para estes, "intervenção humanitária" e "guerra humanitária" ou, em particular, o "bombardeamento humanitário" do Kosovo ou da Líbia são oximoros (ROBERTS, 1993; RIEFF, 2002a; BASS, 2008). Ade- 
mais, o uso de militares para aquilo que somente os próprios podem fazer - prover segurança - complica a proteção e a entrega por parte das organizações civis, visto que os militares dominam a definição de prioridades. "Intervenção humanitária" é a autêntica expressão que precedeu e que talvez retrate o humanitarismo militar de uma maneira mais precisa do que a mais recente e politicamente palatável "responsabilidade de proteger" (ICISS, 2001). ${ }^{2}$ Adam Roberts (2002) é claro: “ação coercitiva exercida por um ou mais estados, envolvendo o uso de força armada em outro estado, sem o consentimento das autoridades deste e com o propósito de prevenir a difusão ampla do sofrimento ou da morte entre seus habitantes." As intervenções militares com substanciais justificativas humanitárias - contra a vontade de um governo ou sem seu genuíno consentimento - figuram de maneira proeminente no pós-Guerra Fria e fazem com que seja possível a ação em áreas onde antes ela não o havia sido.

A intervenção não está envolvida quando uma ação é baseada em uma solicitação livremente feita por um estado ou em seu consentimento não qualificado. Toda política externa busca persuadir ou bajular outros estados, para que mudem de comportamento. A ausência de consentimento é um requisito para que se mereça o rótulo "intervenção", visto que, de outra forma, qualquer envolvimento externo ou tentativa de influenciar outra autoridade política constituiriam uma intervenção. Caso cubra tudo, o termo perde relevância. Em um mundo de poder assimétrico, o que constitui um genuíno "consentimento" também pode ser questionável. Entretanto, o consentimento possui um caráter legal internacional distinto, e sua expressão é uma distinção conceitual para medidas militares contra um estado, assim como para sanções políticas e econômicas, embargos de armamentos e acusação internacional criminal.

O consentimento é um pilar essencial nas fundações da cultura humanitária tradicional, porém a militarização o faz desmoronar. Os humanitaristas não podem ser independentes quando se pautam nos 
militares e em suas prioridades; ademais, a coerção requer tomar parte, o que, por conseguinte, esvazia de sentido a neutralidade e a imparcialidade.

\section{Politização}

O uso dos militares, não importa onde, sem dúvida reflete a alta política (high politics). Contudo, o último quarto de século tem testemunhado uma caça às bruxas de decisões intensamente politizadas, as quais têm alterado de maneira substantiva a cultura humanitária. Há quatro elementos nesse aspecto.

O primeiro se refere à mudança do conflito armado interestatal para o conflito armado intraestatal. As guerras civis são transformativas da cultura, na medida em que os humanitaristas não estão mais lidando com autoridades de governos separados, mas com um conjunto de beligerantes armados. A alcunha impactante "novas guerras", avançada por estudiosos como Mary Kaldor (1999) e Mark Duffield (2001) e por jornalistas como Robert Kaplan (2000), pode levar a uma confusão. Não é exatamente o caso de elementos totalmente novos terem aparecido, mas sim de elementos que se imaginava extintos ou tangenciais e que vieram à tona ou foram combinados de formas que até então tinham pouco destaque (NEWMAN, 2004; KALYVAS, 2001). Sendo assim, a mudança é, com frequência, tão quantitativamente grande, ou os elementos se combinam de maneiras até então tão pouco familiares, que numerosas guerras merecem efetivamente a alcunha "novas" (HOFFMAN; WEISS, 2006).

Muitos países possuem governos centrais cuja existência toma a forma de um membro da ONU, controlando a capital do país ou as principais exportações; pouco se assemelham às suas estáveis contrapartes vestifalianas, exercendo pouco ou nenhum controle de autoridade sobre populações e recursos e certamente não possuindo o monopólio do uso da força (BADIE, 2000). Tais estados sofrem um "divór- 
cio" entre território e autoridade - uma negação da autoridade exclusiva própria da condição de estados (RUGGIE, 1993). As crianças-soldado que, enlouquecidas pelo efeito das drogas, arrancam os membros de civis aterrorizados em Serra Leoa dão uma ideia de parte do horror, assim como a busca por acordo com os quarenta e poucos "principais" movimentos armados de oposição na República Democrática do Congo (RDC). Estados "fracos", "falidos" e "frágeis" vários observadores têm preferências e problemas em relação a todos os adjetivos, mas a realidade é clara - são a cena para a maior parte da ação humanitária contemporânea. A cultura humanitária tradicional tem significado a contínua aplicação de táticas que funcionaram bem no passado para conflitos armados interestatais, mas que são menos úteis em guerras civis atuais. Nem a violência organizada nem o humanitarismo estão mais sob os auspícios exclusivos, ou mesmo predominantes, das autoridades do estado, de modo que a desinstitucionalização da autoridade central soberana significa um impacto reduzido do direito humanitário internacional.

A segunda manifestação da politização se expressa no fato de que doadores governamentais deixaram de investir em desembolsos multilaterais desvinculados através do Sistema ONU - em especial dos três grandes, o Alto Comissariado das Nações Unidas para os Refugiados (ACNUR), a Unicef e o Programa Mundial de Alimentos para vincular os recursos a grupos ou conflitos específicos, agências específicas ou prioridades específicas. A assistência bilateral ou coletiva da Europa é mais vulnerável à politização do que a assistência da ONU ou de ONGs. Com o fim da Guerra Fria, agências bilaterais de ajuda passaram a prover cada vez mais recursos a OIs e ONGs; entretanto, isso não significou o desaparecimento das preocupações políticas por parte de governos. Os doadores não se intimidam acerca do exercício de controle sobre os fundos canalizados através das agências intergovernamentais ou não governamentais. $\mathrm{O}$ sinal de identificação (earmarking) é uma nítida manipulação, e a prioridade 
das agências doadoras dificilmente é mais sutil dentro das agências que dependem de financiamento voluntário, tendo em vista que o poder do bolso é correlativo ao aumento do poder na tomada de decisão.

Ao invés de definir a agenda, conforme ditaria a independência característica da cultura tradicional, as agências de ajuda são com frequência subcontratantes para doadores, cujas preferências são claras e afetam o fulcro dos acontecimentos, ao passo que as preferências dos recebedores são de difícil aferição e podem ser menos impactantes para a base de recursos (HAMMOND, 2008). Países doadores específicos podem exercer influência em uma organização multilateral e ditar a ela como o dinheiro deve ser gasto ou como deve haver um subcontrato envolvendo ONGs locais ou internacionais; eles possuem interesses geopolíticos a proteger e uma base eleitoral doméstica a satisfazer. Prover um Volvo a algum recebedor de ajuda suíça é mais fácil do que prover um Toyota ou um Ford; canalizar os recursos para localidades, beligerantes ou públicos-alvo favorecidos é uma venda mais certa do que a de aportes irrestritos. Apenas os ingênuos ignorariam o tom e as preferências de doadores que bancam, portanto ditam, o ritmo.

Tanto o distanciamento da ajuda irrestrita multilateral, em favor da ajuda bilateral, quanto o distanciamento dos aportes desvinculados (ou centrais) para organizações multilaterais, em favor dos aportes com sinais de identificação (earmarking), ou aportes multibi, são perturbadores para os humanitaristas (BARNETT; SNYDER, 2008). Em 1988, os estados proveram em torno de $45 \%$ da assistência humanitária através de agências da ONU (RANDEL; GERMAN, 2002, p. 21); ao longo dos últimos cinco anos, por volta de $50 \%$ desse tipo de ajuda foi desembolsado através de organizações multilaterais (GHA, 2013, p. 6). Como a maior parte da ajuda possui um sinal de identificação, portanto é vinculada a crises específicas, apenas um pequeno percentual pode ser usado em qualquer lugar que a agência multilateral deseje - da última vez em que isso foi calculado, o per- 
centual foi de aproximadamente 11\%, ou algo próximo a $913 \mathrm{mi}$ lhões de dólares, do total dos 8,7 bilhões de dólares em contribuições humanitárias em 2007 advindas de países-membros do Comitê de Ajuda ao Desenvolvimento (CAD) da Organização para a Cooperação e Desenvolvimento Econômico (OCDE) (GHA, 2009, p. 8).

Enquanto o financiamento multilateral já permitiu maior flexibilidade em perseguir prioridades determinadas pelas agências, atualmente ele é em geral vinculado a atividades ou localidades específicas identificadas pelos financiadores, mesmo quando o financiamento é canalizado através de organizações multilaterais e não governamentais. A simplificação "bilateralização" significa, em essência, vinculação (earmarking) ou multilateralismo de cooptação, na medida em que os doadores governamentais perseguem, de forma explícita, mais compatibilidade entre suas doações e suas prioridades nacionais. O panorama pode variar entre as agências, mas os recursos desvinculados correspondem hoje a $20 \%$ do orçamento de financiamento do Programa das Nações Unidas para o Desenvolvimento e a $30 \%$ das atividades de desenvolvimento conduzidas pela própria ONU, uma imagem reversa do que ocorria há vinte anos, quando os recursos desvinculados eram, de longe, a norma (WEINLICH, [no prelo]). Não obstante alguns argumentem que é pouco o prejuízo causado pela vinculação da ajuda a metas internacionalmente acordadas, tais como os Objetivos de Desenvolvimento do Milênio (ou Metas do Milênio) e o Processo de Apelo Consolidado da ONU (Consolidated Appeal Process, ou CAP, na sigla em inglês), ${ }^{3}$ o planejamento está cada vez mais ligado a prioridades determinadas pelos doadores, e não pelas agências; assim, a abertura ao risco e à experimentação fica virtualmente excluída por esse tipo de condicionalidade.

Com isso, as necessidades das populações afetadas podem ser secundárias na determinação da alocação e dos programas. Por exemplo, dos cinquenta maiores recebedores de assistência entre 1996 e 1999 , os estados da antiga Iugoslávia, Israel/Palestina e Iraque receberam 
metade dos recursos disponíveis (RANDEL; GERMAN, 2002, p. 27). Como contraste, em 2000, a República Democrática do Congo foi o país com o menor nível de necessidades correspondidas - apenas $17,2 \%$ de seu CAP; quatro anos depois, a posição foi ocupada pelo Zimbábue, com 14,2\%. Em 2012, o déficit total foi de 3,3 bilhões de dólares, com apenas $63 \%$ das necessidades correspondidas - o Zimbábue teve o maior percentual de necessidades não correspondidas, com 86\%, e a Libéria, o menor, com 38\% (GHA, 2013, p. 5). O impacto do 11 de setembro já era óbvio em 2002, quando quase metade de todo o financiamento dado aos apelos feitos à ONU por governos doadores foi para o Afeganistão (SMILLIE; MINEAR, 2004, p. 145; OXFAM, 2003, p. 2). Uma década mais tarde, o apelo relativo ao Afeganistão permaneceu entre os mais financiados proporcionalmente às demandas estimadas. Não surpreende que, na ocasião da intervenção de 2011 que depôs Muammar al-Gaddafi, a Líbia tenha imediatamente assumido uma posição entre os CAPs mais financiados, com Sudão, Sri Lanka e Haiti completando a lista dos cinco primeiros. Os menos financiados incluíam África Ocidental, Zimbábue e Djibouti (OCHA, 2011, p. 13). Em 2012, Paquistão, Somália e os Territórios Ocupados encabeçavam a lista (GHA, 2013, p. 6).

Praticamente não há diferença entre as motivações de doadores ocidentais e não tradicionais; a geopolítica com frequência supera os valores humanitários. Por exemplo, financiamentos humanitários não associados ao CAD cresceram exponencialmente de 2011 a 2012, quando a Turquia quase duplicou sua contribuição - a maior parte indo para sua vizinha Síria, responsável por meio milhão de refugiados no país e pela ruptura da economia e da política doméstica turcas (GHA, 2013, p. 4, p. 36).

O terceiro fator da crescente politização resulta das políticas das agências humanitárias, que decidiram que paliativos são insuficientes e que elas deveriam aliviar as causas do sofrimento abordando a 
pobreza e os direitos humanos. A mudança do alívio de emergência para o ataque às causas originárias e para a construção da paz pós-conflito é ambiciosa. Não mais satisfeitos em salvar os indivíduos hoje para colocá-los em perigo amanhã - o ignominioso "morto bem alimentado" é um enquadramento memorável da ajuda na antiga Iugoslávia -, ${ }^{4}$ muitos humanitaristas agora aspiram a nada menos do que melhorar as condições estruturais que ameaçam populações vulneráveis. A ajuda deles também deveria apoiar de alguma forma as negociações e os processos de paz. Ao invés de aplicarem paliativos, eles desejam usar a assistência e a proteção a fim de difundir desenvolvimento, democracia e direitos humanos, criando estados estáveis, efetivos e legítimos (DONINI, 2004; FOX, 2001).

Neutralidade e imparcialidade podem ser obstáculos à promoção dos direitos humanos. Recitar o mantra humanitário pode ser de pouca utilidade; os princípios tradicionais não proveem orientação, ou proveem até mesmo uma má orientação. Como David Rieff (2011, p. 254) nos conta, "o espaço humanitário é uma ideia sentimental; a neutralidade, fictícia; e a imparcialidade, uma abstração... Quanto mais cedo for dado a eles um enterro decente, mais cedo seremos todos capazes de seguir em frente".

O quarto fator é a política após o 11 de setembro. Desde os ataques aos Estados Unidos em setembro de 2001, muitos países viram o contraterrorismo e o humanitarismo como parceiros no combate ao crime - sendo os estados vulneráveis a conflitos considerados santuários e palcos de atuação de terroristas. As organizações humanitárias, nessa perspectiva, fazem parte das campanhas mais amplas voltadas a "corações e mentes", buscando convencer as populações locais das benesses da invasão de exércitos em nome da estabilidade e da liberdade. O secretário de Estado norte-americano, Colin Powell (2001), disse em encontro de agências de ajuda privadas que, "de maneira tão certa quanto nossos diplomatas e militares, as ONGs americanas estão lá fora [no Afeganistão], servindo e se sacrificando nas li- 
nhas de frente da liberdade. As ONGs são uma grande força multiplicadora para nós, uma parte muito importante de nosso time de combate". Sejam ou não opostos aos elementos da política externa ocidental, e em particular dos Estados Unidos, os humanitaristas são com frequência percebidos, no campo, como apoiadores dessa política externa.

Com relação a isso, os governos descobriram que a ação humanitária pode ser instrumental, para que se adiem ou se evitem decisões e ações políticas mais custosas; um "álibi humanitário". A alta comissária da ONU para Refugiados, Sadako Ogata (2005, p. 25), tornou-se uma franca oponente de tais maquinações: "Não há soluções humanitárias para problemas humanitários." Os grandes poderes autorizaram o ACNUR a agir em prol do alívio da Bósnia em parte porque eles queriam aliviar a crescente pressão por uma intervenção humanitária. Porém, de acordo com Alex de Waal (2001, p. 221), na medida em que a ajuda se tornou um substituto da política e um calmante para públicos esperançosos, ela levou "os governos do ocidente e os públicos doadores a se iludirem com a crença no conto de fadas de que sua ajuda pode salvar problemas políticos profundos, quando não pode".

\section{Mercantilização, Parte 1: Externos no Negócio Humanitário}

"Humanitário" e "negócio" estão justapostos por duas razões: provocação e precisão (WEISS, 2013). Justaposição chocante para os que idealizam o empreendimento humanitário, o adjetivo possui conotações essencialmente positivas, ao passo que o substantivo está em geral associado a disputas e embates e em desacordo com os valores e a autoimagem dos verdadeiros crentes. Se a ação humanitária reivindica superioridade moral, o negócio é costumeiramente visto como ocupante de um território menos elevado. Em contraste com os hu- 
manitaristas, os que estão no mercado operam em um lugar em que acordos são costurados, o dinheiro compra acessos, o bem comum é ignorado; em que falar é fácil e as decisões sobre margens de lucro ignoram custos humanos.

Obviamente, humanitaristas externos vindo para resgatar e, nas palavras de Nicholas Wheeler (2000), "salvando estranhos" não é algo divorciado da política, e sim imerso nela; além disso, eles operam no mercado. $\mathrm{O}$ funcionamento diário de todas as agências de ajuda se cruza de formas variadas com os governos de origem e com os governos que as recebem, com as Forças Armadas e com insurgentes armados, assim como com os militares mantenedores da paz (peacekeepers) e com as populações locais; de maneira ainda mais crucial, esse funcionamento entra em confronto com as prioridades dos financiadores. Na condição de agentes engajados na aquisição e na distribuição de recursos, o lugar de onde esses humanitaristas podem conseguir recursos e como e para quem o alívio é entregue são fatores que podem ter consequências significativas para o pessoal envolvido na ajuda, tanto nas sedes quanto nas zonas de guerra. Os funcionários não podem ignorar os pontos de fundo; estes não são apolíticos.

O Bom Samaritano caracteriza as aspirações e as expectativas de numerosos assistentes humanitários. Essa abrangência idealista é compreensível, tendo em vista o requisito de que as organizações humanitárias projetem essa imagem aos públicos ocidentais como parte de uma lógica de mercado: as contribuições advêm de doadores cujos corações e bolsos são tocados pelo registro de uma história e uma imagem de uma criança sozinha sofrendo (duas crianças reduzem o efeito dramático), na mira da guerra, e que somente pode ser salva por generosas doações. Os contribuintes querem ser assegurados de que seus aportes estão diretamente ajudando a melhorar vidas. Folhetos para levantamento de recursos mostram assistentes humanitários vestindo camisas como um logotipo reconhecível, posando ao lado de crianças aparentemente mais felizes e mais bem nutridas. 
Como os empreendedores, os humanitaristas preocupam-se com a imagem e com o marketing em um negócio global em expansão e competitivo, em que fornecedores competem por fatias do mercado. Enquanto o financiamento é mais abundante do que nunca, os recursos ainda são "escassos", tendo em vista a magnitude das necessidades - como foi indicado, menos de dois terços de tais necessidades foram preenchidas, de acordo com os dados disponíveis para o ano mais recente. Para os obstinados humanitaristas que defendem ser apolíticos e se ofendem com a alegação de que não são, o termo "negócio" será perturbador. Os verdadeiros crentes ficarão desconfortáveis em serem analisados como parte de um mercado, visto que o marketing envolve os "4 Ps": produto, preço, praça e promoção. No entanto, todo o negócio começa, conforme Hugo Slim (2012), com a "venda da ideia de constrangimento e compaixão na guerra". A mercantilização no mundo globalizado do século XXI significa que tudo tem um preço - do acesso à autoridade moral e às vidas.

Inovações institucionais geralmente ocorrem depois de guerras, quando os horrores que chocam a consciência expõem as inadequações dos mecanismos de resposta existentes. A repulsa de Henri Dunant diante da carnificina de Solferino levou à criação do CICV em 1865. As consequências sangrentas da Primeira Guerra Mundial e a Revolução Russa levaram à fundação do International Office for Refugees (Comitê Internacional para Refugiados) e da Save the Children (Salvem as Crianças). De modo similar, a Segunda Guerra conduziu a um conjunto de agências - Oxfam, Catholic Relief Services (Serviços Católicos de Alívio), World Vision (Visão Mundial) e CARE, além das pertencentes à família ONU, incluindo a Unicef e o ACNUR. O Movimento dos Médicos Franceses, dando início ao Médicos Sem Fronteiras (MSF), emergiu de uma dissidência de parte dos funcionários do CICV, revoltados com a ortodoxia disfuncional da Organização durante a guerra entre Nigéria e Biafra. 
O fim da Guerra Fria não resultou em transformações do direito internacional ou das instituições internacionais, e sim em novos conflitos e crises, assim como na irrupção de conflitos que vinham se fermentando, porém contidos durante a era de agudas tensões entre o Leste e o Oeste; resultou, ainda, na proliferação de agências humanitárias e na abertura das comportas de recursos. Os orçamentos das agências humanitárias quintuplicaram, passando de algo em torno de 800 milhões de dólares, em 1989, para um valor próximo a 4,4 bilhões, em 1999; de 1999 a 2009, o valor foi quadruplicado, passando para 16,7 bilhões. Depois de atingirem o pico de mais de 20 bilhões de dólares em 2010, os valores caíram para 19,4 bilhões em 2011 e 17,9 bilhões em 2012 (último ano com dados disponíveis) (GHA, 2013, p. 4). Algumas agências específicas (tais como o International Rescue Committee, ou Comitê Internacional de Resgate) ou federações específicas (tais como a Oxfam e a Save the Children) são grandes empresas, ao passo que outras são pequenas, muitas até mesmo artesanais. Enquanto o número de organizações da ONU não cresceu, seus orçamentos cresceram (contabilizando cerca de dois terços do total de desembolso humanitário ligado ao CAD). Ao menos 2.500 ONGs internacionais estão no negócio, mesmo que apenas um décimo delas seja, de fato, significativo. É possível que haja $37 \mathrm{mil}$ ONGs internacionais com alguma relevância para o que Linda Polman (2010) chama de "caravana da crise". Em média, perto de mil ONGs internacionais e locais andam em bando para uma emergência contemporânea.

Na última década, os governos desembolsaram em torno de 110 bilhões de dólares para assistência humanitária. Em 2010 e 2011, eles proveram aproximadamente 14 bilhões por ano e quase 13 bilhões em 2012. As contribuições particulares voluntárias atingiram o pico de 6,3 bilhões de dólares em 2010 (aproximadamente 5 bilhões em 2012), depois de terem batido em 3 bilhões em 2007 (GHA, 2013, p. 20, p. 30). Ademais, nos últimos cinco anos, as operações de paz da 
ONU injetaram entre 8 e 10 bilhões de dólares anuais, com a maioria dos soldados enviada para os mesmos países-alvo. Cada vez mais, os governos estão respondendo a desastres de todos os tipos, e os números se expandiram para além do Ocidente, em direção ao Resto. Enquanto dezesseis estados se comprometeram a apoiar a Bósnia em meados dos anos 1990, a maioria do Ocidente, um grupo diverso de 73 estados participou da conferência de doadores para o Iraque realizada em 2003 em Madri, e 92 estados responderam ao tsunami de dezembro de 2004. Enquanto os governos da OCDE quase dobraram sua assistência entre 2000 e 2010, de 6,7 para 11,8 bilhões de dólares, governos fora da OCDE aumentaram suas contribuições de 35 para 623 milhões de dólares - um aumento de dezoito vezes, embora a partir de uma base bem menor. Em 2011 e 2012, as doações de membros do CAD caíram de 13 para 11,6 bilhões de dólares, ao passo que as de não membros do CAD aumentaram de 0,8 para 1,4 bilhão de dólares (GHA, 2013, p. 4).

E quanto ao número de assistentes humanitários pelo mundo? Abby Stoddard et al. (2006) arriscam o número de mais de 200 mil, mas Peter Walker e Catherine Russ (2010, p. 11) estão, sem dúvida, mais próximos da marca correta: "Não temos a menor ideia do tamanho dessa população." Estimativas incluem todos, do pessoal de limpeza e motoristas no campo aos CEOs nas sedes. Walker e Russ (2010, p. 12) extrapolam os dados da Oxfam e estimam que haja cerca de 30 mil profissionais humanitaristas pelo mundo (tanto locais quanto expatriados).

Não é necessário concordar com a caracterização feita por Naomi Klein (2007), que considera o modelo de negócios para o alívio de emergência um "capitalismo de desastre", para que se reconheça que números globais de 18-20 bilhões de dólares nos últimos anos, com funcionários espalhados pelo planeta e ajudando 75-100 milhões de pessoas, iriam se mostrar, à maior parte dos observadores, como um negócio de grande vulto. A cultura de cooperação humanitária foi 
substituída pela de competição humanitária. Alexander Cooley e James Ron (2002, p. 13) apontam para a "corrida" por recursos, que canaliza prioridades e programas das agências humanitárias - públicas e privadas, grandes e pequenas, religiosas e seculares. O resultado é uma "cultura de contrato" entre os externos que é "profundamente corrosiva" para a alma humanitária.

\section{Mercantilização, Parte 2: Internos em Economias de Guerra}

A contestação da cultura humanitária tradicional também reflete a horrenda realidade das economias locais de países sacudidos pela guerra ou propensos ao conflito. Dois tipos de forças do mercado local influenciam a cultura humanitária contemporânea: interesses econômicos que lucram diretamente com o conflito armado e economias políticas peculiares.

As economias idiossincráticas das zonas de guerra contemporâneas representam formas alternativas de se gerar lucro. O celebrado ditado de Carl von Clausewitz de que a guerra é a continuação da política foi adaptado por David Keen (2000, p. 27, ênfase no original): “a guerra pode ser a continuação da economia por outros meios”. Quando estados estão se despedaçando ou se reajuntando, oportunidades peculiares de lucro abundam. Os balanços têm sido sempre importantes no abastecimento da guerra; capitães da indústria, desde Krupp no Terceiro Reich a Halliburton no Iraque, certamente têm sido mais do que desejosos em ajudar a causa nacional e enriquecer os cofres corporativos e pessoais.

No entanto, a economia local desempenha hoje em dia um papel quantitativa e qualitativamente diferente do de antes (RENO, 2000, p. 44-45; MEHLUM et al., 2002, p. 447-459). Produz-se pouco, destrói-se mais. A economia e a sociedade como um todo sofrem, ao 
passo que indivíduos isolados se beneficiam. Com dinheiro, armamentos e poder em suas mãos, as facções combatentes não têm incentivo para ir à mesa de negociação, ou para nela permanecer; em vez disso, seus interesses são servidos pelo prolongamento da guerra e pela economia que o acompanha e que lhes beneficia diretamente. Atores locais podem concentrar suas energias no controle e na exportação, legal ou ilegal, de alguns recursos-chave, como diamantes e madeira tropical. Em grande medida, o comportamento destrutivo antes, durante e depois das guerras - pode ser explicado pelos incentivos e recompensas econômicos perversos.

A teoria convencional das relações internacionais enfatiza o controle do território como essencial para manutenção da autoridade, mas as guerras contemporâneas compelem os atores a concentrarem suas energias no controle do comércio de commodities-chave. A atividade comercial em muitas guerras parte da premissa da continuação do conflito violento ou é usada para alimentá-lo; às vezes, ambos. Uma forma de comércio criminoso, deformador e debilitante é amiúde um produto da exploração de recursos naturais por interesses privados. Há casos em que a economia formal do estado é manipulada para ganho privado, uma "economia de pilhagem" (HIBOU, 1999, p. 71, p. 96). Em outros casos, criminosos, em especial os que operam como parte de redes transnacionais, contribuem para a erosão do poder do estado, a fim de evitar a regulação e a taxação governamentais (SHELLY, 1995; WILLIAMS, 1994). As oportunidades para se buscar o ganho pessoal e para financiar a guerra levam muitos atores não estatais a enfatizarem o acesso aos recursos naturais, assim como seu controle, o que com frequência resulta em intensificação da violência e das necessidades humanitárias. Em suma, as guerras contemporâneas apresentam oportunidades para o enriquecimento pessoal (proteção e pilhagem), além da perspectiva da entrada de recursos vindos de atores externos. 
Esse último aspecto constitui a segunda distorção local econômica nas guerras atuais. A provisão de recursos externos destinados a ajudar os desamparados conduz as "economias de ajuda". Mais violência significa mais sofrimento e mais ajuda, com mais oportunidades para o lucro local dos poucos bem-aventurados.

Ao se destrinchar a política das sociedades sacudidas pela guerra, revelam-se três problemas para os assistentes humanitários no mercado local. Primeiro, é virtualmente impossível não trabalhar com “destruidores" (STEDMAN et al., 2002), porém os humanitaristas precisam ter uma atenção especial à tentativa de minimizar as chances de que eles acabem inadvertidamente fortalecendo a legitimidade de atores ilegítimos. Relações formais com destruidores reconhecem, de maneira implícita, sua autoridade, e aprimorar sua habilidade no provimento de alívio pode reforçar suas reivindicações de legitimidade.

Segundo, a ajuda humanitária é fungível e pode aliviar os beligerantes de alguns fardos ao se travar uma guerra, o que aumenta efetivamente sua capacidade de continuar lutando, na medida em que diminui as demandas de gestão e de redução dos custos de lidar com as vítimas. Talvez a manifestação mais significativa do que se chamaria usualmente de "corrupção", mas que hoje é rotulado de "custo de se fazer negócio humanitário", consista na compra de acesso através de pagamentos aos que controlam o território. Autoridades centrais do governo e senhores da guerra tentam deslocar o máximo possível de suprimentos de ajuda. As estimativas vão de $15 \%$ a $80 \%$. Um percentual de "imposto" de 25-30\% parece ser a média praticada, que foi, a rigor, o número registrado para a parte reivindicada pelos soldados indonésios no alívio decorrente do tsunami em Aceh, onde um grupo guerrilheiro vinha operando. Esse número foi próximo ao praticado na antiga Iugoslávia, onde o ACNUR cedia parcelas comparáveis aos soldados sérvios (POLMAN, 2010, p. 96-99). 
Terceiro, agências externas podem compor praticamente todo o setor monetizado formal. Os salários internacionais, pagos geralmente em moeda estrangeira, são atrativos não apenas para trabalhadores qualificados, técnicos e para aqueles com proficiência em línguas, mas também para motoristas, seguranças, jardineiros e empregadas domésticas. Com uma remuneração que é de dez a trinta vezes maior em comparação com a posição equivalente na economia local, centenas de pessoas se candidatam para qualquer posição vaga nas agências de ajuda. Além disso, frequentemente a hiperinflação causa danos à economia, resultando nos custos decorrentes da prostituição, das drogas, do contrabando e dos costumes sociais. De acordo com Graciana del Castillo (2009), passar da "economia de guerra" para a “economia de paz" em conflitos como os do Afeganistão e da Libéria talvez seja o desafio mais difícil na construção da paz pós-conflito.

\section{Por uma Cultura Baseada na Evidência}

Em geral, soldados e humanitaristas são vistos como espécies diferentes; mais especificamente, suas respectivas culturas enfatizam valores e perspectivas distintos acerca da violência e do uso da força. Embora abordem a guerra a partir de diferentes posições filosóficas, suas respectivas organizações compartilham ao menos uma característica: os bem-sucedidos aprendem e se adaptam. No entanto, a cultura humanitária dominante desvaloriza, quando não desmerece, a pesquisa aprofundada. Muitos funcionários envolvidos na ajuda são impacientes com relação à cultura da investigação, que veem como antitética à sua própria cultura. ${ }^{5} \mathrm{~A}$ análise é um luxo, um investimento na busca por problemas, e não na sua solução. Para a maior parte, os humanitaristas e seus quadros de confiança negligenciaram ou, ao menos, relegaram a um status terciário, ou mesmo simbólico, dentro de suas organizações as tarefas de, formalmente, identificar problemas, colher dados, formular conclusões e traduzir o aprendizado em 
novas políticas e ações - um processo cumulativo conhecido como "aprendizado".

Grande parte da experiência desde os anos 1990 demonstra que as reações a crises são rotineiras, porém raramente as reflexões sérias fazem parte das descrições do trabalho. Por exemplo, em sua detalhada observação do ACNUR, Gil Loescher (2001) aponta a cultura conservadora da instituição, resistente à mudança e fechada à incorporação de novas ideias e críticas externas. Essa patologia organizacional não é exclusiva do ACNUR, e sim algo generalizado.

O valor do aprendizado não é evidentemente aparente aos praticantes, caso os elos com as políticas e com os programas estejam ausentes. "Adaptação" ocorre quando uma organização identifica modificações de curto prazo para resolver problemas. Contudo, "mudança" ocorre após reflexões substantivas sobre as premissas de modalidades específicas da ação humanitária e sobre as maneiras mais desejáveis de se alterarem políticas, de se adaptarem princípios e, no limite, de se redesenhar e se conduzir uma geração subsequente de operações. "Transformação" se refere à mudança profunda.

Enquanto o sistema humanitário internacional certamente se adaptou ao longo dos anos, os desafios das novas guerras e dos novos humanitarismos são relevantes o suficiente para que fortes mudanças, até mesmo transformações, sejam necessárias no pensamento e na ação estratégicos. Não obstante, as agências de ajuda são muito mais inclinadas a modestos remendos do que a mudanças substantivas, e menos ainda a transformações dramáticas.

Uma comparação entre instituições militares e agências humanitárias - e suas respectivas culturas - se mostra instrutiva. Os críticos costumam ser severos em relação à condição hierárquica e excessivamente financiada dos militares, mas o resultado esperado é a busca pela ordem e pela disciplina que caracteriza um soldado. Os procedimentos operacionais padrão (POPs) refletem uma abordagem para 
gestão e execução de tarefas sob autoridade centralizada. Poder-se-ia esperar que essa cultura fosse rígida e não receptiva ao aprendizado. Porém, o sucesso e a promoção são contingentes à flexibilidade e à abertura à mudança estratégica e tática, assim como depende da disciplina em levar a cabo novos procedimentos que resultam da análise de sucessos e fracassos passados. Novas tecnologias e novos investimentos são rotineiros nesse ponto.

Reconhecer uma necessidade de inovação não é barato, e significativos recursos orçamentários são via de regra dedicados à avaliação e à análise. A defesa nacional ocupa uma posição privilegiada nas lutas governamentais por recursos. Os custos potenciais de ficar para trás - no limite, a derrota - são altos o suficiente para que se assegurem as alocações de recursos para pesquisa, treinamento e investimento. Os incentivos materiais para que os militares tenham sucesso nos campos de batalha em geral garantem a generosidade parlamentar diante das demandas orçamentárias. Não se cogita a retirada do negócio ou o rebaixamento de sua condição de prioridade máxima.

O contraste com a cultura e as despesas da esmagadora maioria das organizações humanitárias dificilmente poderia ser maior. Estas geralmente imploram por recursos que podem ser inadequados à reação e ao provimento de alívio no decorrer de uma guerra; os orçamentos não são garantidos, refletindo um perpétuo levantamento de recursos. Agências de ajuda quase sempre trabalham com outros atores. Na mobilização de recursos, elas confiam nos doadores. No provimento de alívio e proteção, seu trabalho depende do acesso facilitado por um grupo de outras agências, incluindo soldados. Em suma, os desafios de se angariar recursos e se assegurar o acesso com frequência fazem com que a ação humanitária seja contingente a um alinhamento entre os desejos dos doadores e os caprichos dos interlocutores. Agências de ajuda individuais são engrenagens essenciais de uma máquina internacional bem mais ampla. Isso é particularmente 
evidente nos ambientes operacionais não permissivos dos atuais conflitos armados.

A despeito da mudança sempre constante do ambiente institucional e da característica das diferentes zonas de guerra, os humanitaristas não possuem campos de treinamento ou laboratórios para experiências, a fim de ajudá-los na superação da inércia burocrática e das dificuldades operacionais. Além de um programa ocasional de mestrado, não há instituições acadêmicas especializadas. E praticamente nenhum recurso, ao menos como percentual dos orçamentos totais, é alocado para o entendimento das atuais e das precedentes operações, com a finalidade de mudar táticas e estratégias. De fato, tem-se geralmente como virtude o que em outras organizações seria visto com uma séria deficiência: seguir para a próxima crise o mais rápido possível, sem que se tenha colhido dados ou digerido a evidência da última catástrofe, ou que se a tenha avaliado e tentado formular políticas e abordagens alternativas. $\mathrm{O}$ direito de se vangloriar e as mais altas avaliações vão para aqueles que gastam o mínimo com treinamento e avaliação, ou outras despesas que supostamente indicam desperdício.

Seguindo o questionamento do relatório anual da Federação Internacional das Sociedades da Cruz Vermelha e do Crescente Vermelho, por que é tão difícil exercer um "julgamento humanitário para analisar contexto” (IFRC, 2003, p. 36)? David Kennedy dá a resposta: "Quando os dados são incertos, os humanitaristas se guiam por intuições, inferências e concepções acerca da melhor prática.” Na pressa em responder, eles repetem "respostas passadas" que podem um dia ter feito sentido. Porém, ao invés de repetições e reações irrefletidas, reflexões pragmáticas deveriam orientar as agências: "Um pragmatismo de consequências se depara com dificuldades, quando esse tipo de expertise substitui uma análise cuidadosa das consequências de longo e médio prazos." E a cultura humanitária deveria mudar porque os humanitaristas "tendem a se sentir desconfortáveis quando se 
veem fazendo o tipo de escolhas distributivas entre vencedores e perdedores que parece ser requisito de um pragmatismo de consequências" (KENNEDY, 2005, p. xxiii-xxiv). Com base em suas marcantes experiências no Médicos Sem Fronteiras, Fiona Terry (2002, p. 44) usa o título de seu livro para fazer uma pergunta obviamente retórica: Condenadas a repetir? Ela e outros detalham oportunidades perdidas, desde os anos 1990, para o aprendizado, o que levou Ian Smillie e Larry Minear (2004, p. 224) a recomendarem "uma abordagem mais ampla [...] que coloque o aprendizado no centro".

Infelizmente, parar para refletir é duplamente problemático. Não apenas porque há poucos recursos disponíveis para a reflexão, como também porque a estrutura de incentivos recompensa os que estão na ponta da linha de resposta. A comparação entre a abordagem dos militares e a dos humanitaristas ao aprendizado gera uma enorme disparidade, tendo em vista a baixa prioridade atribuída pelos últimos ao entendimento e à adaptação às dinâmicas que criam obstáculos à efetiva ação em zonas de guerra.

A ausência de uma orientação para o aprendizado é estrutural. Randolph Kent (2004, p. 9) notou, há uma década, que a "formulação estratégica requer ao menos o envolvimento de todos os principais componentes dentro de uma organização - em outros termos, um grau incomum de cooperação intraorganizacional entre os responsáveis por emergências, políticas, desenvolvimento e orçamento". Por conseguinte, a formulação de uma estratégia abarca dois passos: primeiro, o comportamento de aprendizado e de adaptação; e, segundo, a disseminação de tal conhecimento e a garantia de sua implementação coerente. Para que o pensamento estratégico humanitário se transforme em ação estratégica, as agências precisam desesperadamente de um programa para desenvolver e fortalecer capacidades de analisar a si próprias e a todo o sistema.

Aprimoramentos são necessários por todo o sistema, mas as agências individuais deveriam começar pelo desenvolvimento e fortaleci- 
mento de três capacidades analíticas, como parte de uma cultura humanitária diferente. A primeira é uma melhor inteligência. Um grande obstáculo à operação das agências no campo e ao planejamento de futuros empreendimentos é a ausência de informações oportunas e precisas, sem as quais os humanitaristas podem recair no equívoco de ajudar partes manipuladoras e participantes de outros esforços contraproducentes. ${ }^{6}$ A informação sobre as intenções e as condutas dos atores em cena pode ajudar na seleção das táticas, na negociação do acesso e no sequenciamento de outros aspectos das operações que, no limite, contribuem para seu sucesso.

As agências de ajuda geralmente entram nos teatros de operação sem sequer o mais básico conhecimento sobre os beligerantes, sua história e a dinâmica da área onde a violência se dá. Além desse conhecimento inadequado, é raro que existam funcionários dedicados a monitorar a política local quando a operação já está em curso, a fim de informar os formuladores de política e os tomadores de decisão. $\mathrm{O}$ conhecimento das sociedades e das línguas locais é obviamente uma lacuna, e tal ausência já foi lamentada por muitos praticantes de ajuda humanitária muito antes da bola da vez se tornar os países islâmicos, para os quais a expertise ocidental é particularmente insuficiente. No entanto, há obstáculos menos óbvios, como a maneira pela qual várias fontes de inteligência humanitária podem ser desenvolvidas e utilizadas - dados e análises dos beligerantes, das condições locais, dos recursos humanitários nativos e dos impactos da assistência.

A segunda capacidade é relacionada à primeira, qual seja: a necessidade de aprimoramento da memória institucional, de documentação das atividades e das repercussões delas derivadas. O alerta de George Santanyana, segundo o qual "aqueles que não conhecem as lições da história estão fadados a repeti-las", tem pouca ressonância entre os humanitaristas. O que os analistas de negócios chamariam de "curva de aprendizagem achatada" caracteriza o empreendimento humanitário, cujos participantes comparam as notas principalmente com 
aqueles que residem na mesma câmara de eco. Entender o escopo e a natureza dos problemas e avaliar criticamente as opções são cruciais para que se evitem erros já cometidos e não se deixe escapar alternativas. As agências deveriam estabelecer unidades formais de documentação e pesquisa. A memória institucional poderia se fazer valer do suporte técnico de estudantes de pós-graduação em história e ciências sociais, a fim de buscar fatos e analisá-los, um processo que também poderia servir de ajuda a um futuro recrutamento e à criação da próxima geração de praticantes de ajuda humanitária.

A terceira capacidade são as comunicações e a construção de redes (networking), o que deve acompanhar a melhoria da inteligência e da memória institucional na coleta e no processamento de dados para os que estiverem na iminência de assumirem novas posições ou entrarem em novos teatros de operação. A discussão acerca do mercado indicou as dificuldades estruturais e culturais na promoção da coordenação e da coerência dentro do sistema humanitário internacional. A eliminação completa dessas tensões é irreal; mesmo assim, uma melhor comunicação é sem dúvida mais viável e essencial para uma melhor coordenação ou mesmo para uma modesta coerência. Um passo importante na direção correta seria a formação de relações de longo prazo entre instituições de pesquisa cruciais - tanto universidades quanto think tanks - e agências operacionais.

\section{Ética Consequencialista}

A rigor, a mudança na cultura requer o reconhecimento de um único princípio de primeira ordem - a inviolabilidade da vida ou da dignidade humana -, mas também requer relegar a um status de segunda ordem os três princípios operacionais que formam o núcleo da cultura humanitária tradicional - independência, neutralidade e imparcialidade. Estes são meios, não fins; podem ajudar, mas não são princípios morais inquestionáveis. Eles ocupam necessariamente um lugar menos prioritário nos cálculos mais consequencialistas acerca dos 
inputs específicos baseados no melhor conhecimento de conflitos armados determinados e de seus prováveis resultados e impactos operacionais.

A era da inocência não existe mais, se é que um dia existiu. ${ }^{7}$ Ao invés de se apressarem, os humanitaristas precisam reduzir o ritmo e superar o traço cultural dominante do "precisamos de ação imediata" (LEVINE; CHASTRE, 2004, p. 19). Guerras não são tsunamis ou terremotos, de modo que os humanitaristas devem abordá-las de formas diferentes. A mudança cultural necessária é dramática: para navegarem pelos cardumes das águas turbulentas das zonas de guerras contemporâneas, eles têm de refletir antes de agir. "O remédio é um pragmatismo mais consciencioso", sugere David Kennedy (2005, p. 309). "Extirpando as pré-concepções, desencantando as doutrinas e ferramentas institucionais que substituem a análise, insistindo em uma análise rigorosa de custos e benefícios, poderemos atingir um humanitarismo que iluminaria seus próprios lados negros."

Um humanitarismo estratégico bem pensando e informado é mais apropriado do que a aplicação rígida de princípios tradicionais, de segunda ordem, ao menos por quatro razões: as metas com frequência entram em conflito; as boas intenções podem ter consequências catastróficas; os fins podem ser atingidos de múltiplas maneiras; e as escolhas são necessárias, mesmo que haja menos opções do que seria o ideal.

Os humanitaristas deveriam, portanto, deixar de lado a ideologia, pesar as alternativas e considerar os resultados de longo prazo. Em poucas palavras, os julgamentos não deveriam derivar de princípios apriorísticos de segunda ordem. Avaliações empíricas são essenciais, visto que os lados negros da virtude podem prevalecer sobre os benefícios do humanitarismo; a disponibilidade de recursos é um argumento insuficiente para a ação. Há sempre vencedores e perdedores, resultados virtuosos e custos horrendos. O humanitarismo provê 
um vocabulário e um aparato institucional idealistas, no entanto ele precisa ser julgado por suas consequências, e não suas intenções, pela qualidade dos resultados e impactos, e não meramente pelos inputs e outputs.

Seria injusto e impreciso sugerir que nada mudou depois do fim da Guerra Fria. Os esforços das últimas duas décadas apontam para um gradual crescimento do apetite pela pesquisa em ciências sociais por parte dos praticantes de ajuda humanitária. A Oxfam do Reino Unido foi líder nesse aspecto, com funcionários pagos para pesquisa e avaliação. Observadores experientes são familiarizados com os esforços do CICV em torno do Projeto Avenir, com o Projeto Sphere, da Federação Internacional das Sociedades da Cruz Vermelha e do Crescente Vermelho, e com o Active Learning for Accountability and Performance in Humanitarian Action (Aprendizado Ativo para Responsividade e Performance em Ação Humanitária, ou ALNAP, na sigla em inglês). Outras fontes também ajudaram na geração de dados e de padrões de medida, tais como o Humanitarianism \& War Project (Projeto Humanitarismo \& Guerra, a princípio na Brown University, depois na Tufts University), o Overseas Development Institute (Instituto de Desenvolvimento Ultramarino), a Global Humanitarian Assistance (Assistência Humanitária Global) e o Centre for Humanitarian Dialogue (Centro para Diálogo Humanitário), além de outros pesquisadores universitários.

Um indicador significativo da necessidade de mudança da cultura dominante foi o Emergency Capacity Building Project (Projeto de Construção de Capacitação para Emergências, ou ECB, na sigla em inglês), um esforço de uma década financiado principalmente pela Fundação Bill e Melinda Gates. ${ }^{8}$ Em 2004, diretores de emergência de sete das maiores ONGs - CARE International, Catholic Relief Services, International Rescue Committee, Mercy Corps, Oxfam Reino Unido, Save the Children e World Vision International - focaram em desafios persistentes. Um relatório inicial do ECB sobre ca- 
pacidade identificou lacunas centrais obstaculizando a habilidade em prover repostas oportunas, efetivas e de qualidade. Entre 2005 e 2013, vinte publicações (pesquisas e guias) vieram a lume.

Uma melhor informação e melhores linhas de base são, sem dúvida, um passo na direção correta, mas o aprendizado bem-sucedido requer não apenas diagnósticos e prescrições (por agentes externos e internos), como também a implementação. Ainda assim, a cultura dominante das agências humanitárias resiste às curas para o que aflige o sistema. Três analistas bem situados notam que, desde o trauma de Ruanda, "o setor humanitário testemunhou uma tendência (incompleta) em direção à profissionalização" (DIJKZEUL et al., 2013, p. s4). ${ }^{9}$

"Incompleta" é, na verdade, uma descrição generosa. Em razão do fervor frenético para reagir a crises, ligado à sua marca maior, que é o comprometimento em salvar estranhos, as organizações humanitárias dedicam muito pouca energia e muito pouco de seu próprio recurso ao entendimento da natureza de um desastre específico e ao ajuste de respostas de acordo com essa especificidade. Fazer algo ou não fazer nada podem ser opções aceitáveis. O que Larry Minear e eu escrevemos há duas décadas continua saliente (MINEAR; WEISS, 1993): “Não simplesmente faça algo, fique parado.” A reflexão é um pré-requisito para a ação e amortizará melhor os investimentos do que reações precipitadas, ainda que sinceras e bem-intencionadas.

Ao passo que "humanitário" possui uma conotação de preocupação altruísta, "estratégico" faz soar o sino do cálculo frio, ao menos para muitos ouvidos humanitários. O pensamento estratégico não é meramente para especialistas em política externa ou em segurança internacional, mas também para humanitaristas. O pensamento estratégico seria amortizado pela ação estratégica. Salvar vidas é não apenas uma questão do coração, mas também da mente. Amenizar o idealismo com capacidades analíticas aprimoradas fortalecerá a tração do 
sistema humanitário internacional, uma abordagem que o Myron Wiener (1998) tardio nomeou, há muito tempo, de "humanitarismo instrumental".

Uma ação humanitária baseada na evidência também tem de ser condicionada pelo contexto. As ciências sociais podem ser úteis no ajuste das atividades às sensibilidades locais e no monitoramento das operações em andamento. Fontes alternativas devem ser buscadas, incluindo jornalistas que possam ter acesso a líderes políticos e a áreas politicamente marginais ou negligenciadas, além de motoristas de caminhão e de táxi que têm noções sobre a logística local. A participação de usuários e grupos-alvo é parte de uma parceria precípua de pesquisa (HAMMOND, 2008).

Os praticantes de ajuda humanitária deveriam ser mais receptivos diante das ciências sociais, cuja força advém da sua habilidade em coletar, organizar, interpretar e disseminar descobertas baseadas em evidência e condicionadas pelo contexto, além de recomendações políticas (policy recommendations) e diretrizes ajustadas ao caso. Essa recomendação não é uma justificativa que serve aos propósitos do próprio pesquisador, mas uma convicção de que mais reflexão e menos reação não apenas ajudariam a aprimorar a eficiência do empreendimento humanitário, como também proveriam melhor assistência a populações vulneráveis.

Há mais de uma década, Larry Minear (2002, p. 7) argumentou que "a adaptação das organizações humanitárias às novas realidades tem sido, em sua grande maioria, letárgica e fleumática”. Os humanitaristas ainda são deficientes em aprendizagem - eles não possuem nem as capacidades nem as inclinações culturais para processarem informação, corrigirem erros e vislumbrarem estratégias e táticas alternativas. A entrega e a proteção, e não a análise, são propriamente as suas preocupações, porém os funcionários da assistência humanitária deveriam reconhecer o valor agregado dos cientistas sociais. Uma 
parceria seria benéfica tanto para as agências de ajuda quanto para os acadêmicos, assim como para os habitantes das sociedades atingidas pela guerra.

Parte da mudança da cultura humanitária dominante envolverá o equivalente humanitário da ciência militar. Por muito tempo, os praticantes da ajuda humanitária têm falado em se tornar mais profissionais, no entanto não têm se disposto a aceitar a disciplina e os custos que decorriam necessariamente disso. ${ }^{10}$ Embora os dados e a pesquisa estejam mais numerosos do que no período imediatamente posterior à Guerra Fria, uma parcela excessiva do alívio e da proteção é conduzida por anedota e angústia, intuição e instinto, ao invés de pela evidência, pela estratégia e pelos resultados. O dinheiro alocado pela Fundação Gates e por outros doadores é bem-vindo e útil, não há dúvidas quanto a isso; porém, as próprias agências deveriam destinar mais recursos orçamentários de financiamento para o aprimoramento de seu conhecimento de base e para o treinamento de seus funcionários.

Não obstante os humanitaristas se arrepiarem com a comparação, militares profissionais - ao contrário de humanitaristas profissionais - possuem uma cultura que valoriza o aprendizado e investe substanciais recursos humanos e financeiros na infraestrutura institucional destinada a reunir os aprendizados e agir de acordo com eles. Academias militares são expressões de como isso funciona; operações anteriores e atuais são dissecadas, novos procedimentos são tentados e testados e aspirantes a soldados são educados sobre as melhores práticas e táticas de adaptação diante de especificidades do campo. O desenvolvimento da carreira requer um tempo para o estudo e a reflexão, antes que tarefas sejam distribuídas. Operações em curso possuem historiadores. Enquanto os críticos podem ridicularizar essas orientações como sendo resultados de uma "gordura" institucional e de alocações excessivamente generosas por parte de parlamentos, elas são mais precisamente vistas como uma diferença cultural essencial 
que os humanitaristas deveriam emular. É demasiado simplista desmerecer sumariamente os militares por terem combatido na última guerra. Eles devotam energias profissionais substantivas no aprendizado das lições; os humanitaristas quase nunca fazem mais do que correr para a próxima emergência.

A cultura humanitária deveria mudar de reação para reflexão-e-ação, de ser simplesmente forte e sincera, para ser também inteligente. A marca registrada dos humanitaristas é a resposta pelo coração. Contudo, uma dose equivalente de firmeza bem informada é necessária. Por quê? Os funcionários humanitários são alvos específicos das partes em guerra; a insígnia não mais garante a proteção; e as respostas emergenciais são apenas um elemento de processos complicados de resolução de conflito e construção de paz. Com os humanitaristas competindo em duas frentes - por recursos dos doadores e por acesso com os beligerantes -, eles também deveriam dedicar mais energia para pensar metas e papéis, fins e meios, resultados e impactos, e para perseguirem novas estratégias, táticas e ferramentas para as guerras contemporâneas.

A reconsideração da independência, da imparcialidade e da neutralidade tem levado a uma crise de identidade coletiva. Em um mercado cada vez mais competitivo, a proposição aqui é direta: aqueles que têm clareza sobre os custos de desviar dos princípios de conduta serão mais bem-sucedidos em ajudar as populações afetadas do que os que não têm princípios (oportunistas) ou que são inflexíveis (ideólogos).

A modéstia é uma virtude para os provedores de assistência e para os cientistas sociais. No entanto, muitos dos humanitaristas mais comprometidos gostariam de nos fazer acreditar no "imperativo" humanitário, ${ }^{11}$ a obrigação moral de tratar as populações afetadas de maneira similar e de reagir a todas as crises de maneira consistente. Contudo, as crises nunca são as mesmas e essa noção permeia a política, que consiste em traçar linhas, assim como pesar as opções e os recur- 
sos limitados, para que duras decisões sejam tomadas sobre a produção do maior bem, ou ao menos do menor mal, tendo em vista que haverá invariavelmente mais demanda do que oferta humanitária.

Uma descrição mais precisa da ida ao resgate nas guerras de hoje em dia seria o "impulso" humanitário - em alguns casos, devemos e podemos agir; em outros, podemos, mas não devemos. A ação humanitária é desejável, não obrigatória. O impulso humanitário é permissivo; o imperativo humanitário, peremptório. Alterar a inclinação das curvas de oferta e demanda requer uma análise pragmática, e não a rígida aplicação de princípios morais inquestionáveis. Embora na moda, um manequim humanitário, em especial tendo sido ajustado a partir do tecido de outra época, não mais veste bem.

Com frequência, a palavra "dilema" é empregada para descrever a dolorosa tomada de decisão, mas a palavra "embaraço" é mais adequada. Um dilema envolve dois ou mais cursos de ação alternativos, com consequências não antecipadas, inevitáveis e igualmente indesejáveis. Se as consequências são igualmente ruins, permanecer à margem é uma opção viável e moral. Os humanitaristas encontram-se perplexos, ou em um embaraço, mas não estão nem devem ficar imobilizados pelas guerras contemporâneas. O ponto-chave reside em fazer um esforço de boa-fé, no intuito de analisar as vantagens e desvantagens de qualquer curso de ação, militar ou civil, e optar pelo que possa ser a opção menos ruim.

Os cálculos são agonizantes, mas inevitáveis para os que trabalham hoje no negócio humanitário. O custo de se desprezarem as lições é maior do que o gasto em aprender com elas. A ética consequencialista é essencial.

\section{Conclusão}

Abordar a ação humanitária contemporânea como uma atividade que é profundamente militarizada e politizada e também comercial será 
escandaloso para aqueles que a entendem como uma atividade de cura, baseada exclusivamente em valores e princípios. Grande parte das pessoas torna-se humanitarista ou faz doações para agências de ajuda porque se importam com o alívio do sofrimento, e não porque querem se envolver em uma manipulação militar e política ou porque querem lucrar. No entanto, é míope a visão que ignora o revestimento militar e político dos esforços contemporâneos em zonas de guerra e a dinâmica de mercado de um negócio que é multibilionário - oferta, demanda, competição, distorções de mercado, monopólios, custo, preço, eficiências e viés do investidor influenciam a maneira pela qual se dá o fluxo de dinheiro em situações de emergências e a maneira pela qual as agências de ajuda respondem.

Militarização, politização e mercantilização não são toda a verdade do projeto humanitário, mas são componentes essenciais. É crucial entender como o sistema humanitário internacional funciona, caso se busque aprimorar suas operações e atenuar, quiçá eliminar, a cultura de competição e contraprodutividade. As ciências sociais baseadas em evidência e condicionadas pelo contexto podem melhorar a performance do empreendimento humanitário. A cultura deve se distanciar das decisões baseadas em inputs e outputs, em direção à consideração dos resultados e dos impactos. A transformação da guerra e o mercado exigem a transformação também do multilateralismo.

A politização, não menos do que a militarização, coloca em questionamento a independência, a neutralidade e a imparcialidade que antes eram fundações sólidas da cultura e da ação humanitárias. Esses dois fatores já solapariam, por si só, a cultura humanitária dominante, tradicional. No entanto, a terceira e menos óbvia influência, o mercado humanitário, combina as outras duas, de modo que as zonas de guerra atuais são marcadamente diferentes das anteriores. O humanitarismo não é o que costumava ser, porém poderia se aproximar de seus elevados ideais, caso o pensamento estratégico fosse um prelúdio rotineiro da ação estratégica. 


\section{Notas}

1. Ver Weiss (1999).

2. Interpretações por parte de membros da Comissão: Gareth Evans (2008) e Ramesh Thakur (2006). Ver ainda: Bellamy (2009), Orford (2011) e Hehir (2012). A interpretação do autor está em Weiss (2012).

3. Ver Jenks ([no prelo]).

4. A frase de Fred Cuny foi popularizada por Roberta Cohen e Francis M. Deng (1998a, p. 15; 1998b, p. 10).

5. Esta seção se pauta em Hoffman e Weiss (2008).

6. Ver Stanley Foundation (2003) e Weiss e Hoffman (2005).

7. Ver Weiss (1999) e Wood et al. (2001).

8. Ver: <http://www.ecbproject.org/>.

9. Os autores são editores convidados para um número especial dedicado a esse tópico.

10. Para uma discussão sobre as disputas internas, inclusive entre gerações fundadoras e posteriores, ver Vallaeys (2004) e Hopgood (2005).

11. Ver Weiss ([no prelo]).

\section{Referências Bibliográficas}

ADEBAJO, Adekeye. UN Peacekeeping in Africa: From the Suez Crisis to the Sudan Conflicts. Boulder: Lynne Rienner, 2011.

BADIE, Bertrand. The Imported State: The Westernization of the Political Order. Stanford: Stanford University Press, 2000.

BARNETT, Michael. Empire of Humanity: A History of Humanitarianism. Ithaca: Cornell University Press, 2011. 
; SNYDER, Jack. The Grand Strategies of Humanitarianism. In: BARNETT, M.; WEISS, T. G. (Org.). Humanitarianism in Question: Politics, Power, Ethics. Ithaca: Cornell University Press, 2008. p. 143-171.

BASS, Gary. Freedom's Battle: The Origins of Humanitarian Intervention. Nova York: Random House, 2008.

BELLAMY, Alex J. Responsibility to Protect: The Global Effort to End Mass Atrocities. Cambridge: Polity Press, 2009.

CENTER ON INTERNATIONAL COOPERATION. Global Peace Operations 2013. Boulder: Lynne Rienner, 2013.

COHEN, Roberta; DENG, Francis M. Exodus within Borders. Foreign Affairs, v. 77, n. 4, 1998a.

Masses in Flight: The Global Crisis of Internal Displacement. Washington: Brookings Institution, 1998b.

COOLEY, Alexander; RON, James. The NGO Scramble: Organizational Insecurity and the Political Economy of Transnational Action. International Security, v. 27, n. 1, 2002.

DEL CASTILLO, Graciana. Rebuilding War-Torn States: The Challenge of Post-Conflict Economic Reconstruction. Oxford: Oxford University Press, 2009.

DIJKZEUL, Dennis; HILHORST, Dorothea; WALKER, Peter. Introduction: Evidence-based Action in Humanitarian Crises. Disasters, v. 37, n. 1, Jul. 2013.

DONINI, Antonio. The Future of Humanitarian Action: Implications of Iraq and Other Recent Crises. Medford: Tufts University, 2004.

DUFFIELD, Mark. Global Governance and the New Wars: The Merging of Development and Security. Londres: Zed Books, 2001.

EVANS, Gareth. The Responsibility to Protect: Ending Mass Atrocity Crimes Once and For All. Washington: Brookings, 2008.

FORSYTHE, David P. The Humanitarians: The International Committee of the Red Cross. Cambridge: Cambridge University Press, 2005. 
FOX, F. New Humanitarianism: Does It Provide a Moral Banner for the 21st Century? Disasters, v. 25, n. 4, p. 275-289, 2001.

GHA - Global Humanitarian Assistance. Global Humanitarian Assistance Report 2009. Somerset: Development Initiatives, 2009. Disponível em: $<$ http://www.globalhumanitarianassistance.org/analyses-and-reports/gha-reports/gha-reports-2009>.

Global Humanitarian Assistance Report 2013. Somerset: Development Initiatives, 2013. Disponível em: <http://www.globalhumanitarianassistance.org/wp-content/uploads/2013/07/GHA-Report-20131.pdf>.

HAMMOND, Laura. The Power of Holding Humanitarianism Hostage and the Myth of Protective Principles. In: BARNETT, M.; WEISS, T. G. (Org.). Humanitarianism in Question: Politics, Power, Ethics. Ithaca: Cornell University Press, 2008. p. 172-195.

HEHIR, Aidan. The Responsibility to Protect: Rhetoric, Reality and the Future of Humanitarian Intervention. Houndmills: PalgraveMacmillan, 2012.

HIBOU, Beatrice. The "Social Capital" of the State as an Agent of Deception. In: BAYART, Jean-Francois; ELLIS, Stephen; HIBOU, Beatrice. The Criminalization of the State in Africa. Bloomington: Indiana University Press, 1999.

HOFFMAN, Peter J.; WEISS, Thomas G. Sword and Salve: Confronting New Wars and Humanitarian Crises. Lanham: Rowman \& Littlefield, 2006.

Humanitarianism and Practitioners: Social Science Matters. In: BARNETT, M.; WEISS, T. G. (Org.). Humanitarianism in Question: Politics, Power, Ethics. Ithaca: Cornell University Press, 2008. p. 264-285.

HOPGOOD, Stephen. Keepers of the Flame: Amnesty International and the Politics of Authority. Ithaca: Cornell University Press, 2005.

ICISS - International Commission on Intervention and State Sovereignty. The Responsibility to Protect. Ottawa: International Development Research Centre, 2001.

IFRC - International Federation of Red Cross and Red Crescent Societies. World Disasters Report 2003: Focus on Ethics in War. West Bloomfield: Kumarian, 2003. 
JENKS, Bruce. The Financing of the UN Development System and the Future of Multilateralism. In: BROWNE, S.; WEISS, T. G. (Org.). Post-2015 UN Development: Making Change Happen. Londres: Routledge, [no prelo].

KALDOR, Mary. New \& Old Wars: Organized Violence in a Global Era. Stanford: Stanford University Press, 1999.

KALYVAS, Stathis N. "New" and "Old" Civil Wars: A Valid Distinction? World Politics, v. 54, n. 1, p. 99-118, Oct. 2001.

KAPLAN, Robert. The Coming Anarchy: Shattering the Dreams of the Post-Cold War. Nova York: Random House, 2000.

KEEN, David. Incentives and Disincentives for Violence. In: BERDAL, M.; MALONE, D. Greed and Grievance: Economic Agendas in Civil War. Boulder: Lynne Reinner, 2000.

KENNEDY, David. Dark Sides of Virtue: Reassessing International Humanitarianism. Princeton: Princeton University Press, 2005.

KENT, Randolph. Humanitarian Futures: Practical Policy Perspectives. HPG Network Paper 46, Apr. 2004.

KLEIN, Naomi. The Shock Doctrine: The Rise of Disaster Capitalism. Nova York: Metropolitan Books, 2007.

LEVINE, Simon; CHASTRE, Claire. Missing the Point: An Analysis of Food Secuirty Interventions in the Great Lakes. HPN Network Paper 47. Londres: Overseas Development Institute, 2004.

LOESCHER, Gil. The UNHCR and World Politics: A Perilous Path. Oxford: Oxford University Press, 2001.

MEHLUM, Halvor; MOENE, Karl Ove; TORVIK, Ragnar. Plunder \& Protection, Inc. Journal of Peace Research, v. 39, n. 4, 2002.

MINEAR, Larry. The Humanitarian Enterprise: Dilemmas and Discoveries. West Bloomfield: Kumarian, 2002.

; WEISS, Thomas G. Humanitarian Action in Times of War: A Handbook for Practitioners. Boulder: Rienner, 1993.

NEWMAN, Edward. The "New Wars" Debate: A Historical Perspective Is Needed. Security Dialogue, v. 35, n. 2, p. 173-189, 2004. 
OCHA - Office for the Coordination of Humanitarian Affairs. Chapeau of the Mid-Year Review of the Humanitarian Appeal for 2011. Genebra: UN, 2011.

OGATA, Sadako. The Turbulent Decade: Confronting the Refugee Crises of the 1990s. Nova York: Norton, 2005.

ORFORD, Anne. International Authority and the Responsibility to Protect. Cambridge: Cambridge University Press, 2011.

OXFAM. Beyond the Headlines: An Agenda for Action to Protect Civilians in Neglected Countries. Oxford: Oxfam International, 2003.

PICTET, Jean. The Fundamental Principles of the Red Cross. Genebra: ICRC, 1979.

PINKER, Steven. The Better Angels of Our Nature. Nova York: Viking, 2011.

POLMAN, Linda. The Crisis Caravan: What's Wrong with Humanitarian Aid? Nova York: Henry Holt, 2010.

POWELL, Colin. Remarks to the National Foreign Policy Conference for Leaders of Nongovernmental Organizations. 26 out. 2001.

RANDEL, Judith; GERMAN, Tony. Trends in Financing of Humanitarian Assistance. In: MACRAE, J. (Org.). The New Humanitarianisms: A Review of Trends in Global Humanitarian Action. Londres: Overseas Development Institute, 2002.

RENO, William. Shadow States and the Political Economy of Civil War. In: BERDAL, M.; MALONE, D. Greed and Grievance: Economic Agendas in Civil War. Boulder: Lynne Reinner, 2000.

RIEFF, David. A Bed for the Night: Humanitarianism in Crisis. Nova York: Simon \& Schuster, 2002a.

Humanitarianism in Crisis. Foreign Affairs, v. 81, n. 6, p. 111-121, Nov.-Dec. 2002b.

Afterword. In: MAGONE, C.; NEUMAN, M.; WEISSMAN, F. (Org.). Humanitarian Negotiations Revealed: The MSF Experience. Londres: Hurst, 2011. 
ROBERTS, Adam. Humanitarian War: Military Intervention and Human Rights. International Affairs, v. 69, n. 3, p. 429-449, 1993.

The So-Called "Right" of Humanitarian Intervention. In: Yearbook of International Humanitarian Law 2000. v. 3. Haia: T. M. C. Asser, 2002. p. 3-51.

SHELLY, Louis. Transnational Organized Crime: An Imminent Threat to the Nation-State. Journal of International Affairs, v. 48, n. 2, p. 464-489, 1995.

SLIM, Hugo. Marketing Humanitarian Space: Argument and Method in Humanitarian Persuasion. In: Essays in Humanitarian Action. Oxford: Oxford Institute for Ethics, Law, and Armed Conflict, University of Oxford, 2012.

SMILLIE, Ian; MINEAR, Larry. The Charity of Nations: Humanitarian Action in a Calculating World. Bloomfield: Kumarian, 2004.

STANLEY FOUNDATION. UN on the Ground. Muscatine: Stanley Foundation, 2003.

STEDMAN, Stephen John; ROTHCHILD, Donald; COUSENS, Elizabeth M. (Org.). Ending Civil Wars: The Implementation of Peace Agreements. Boulder: Lynne Rienner, 2002.

STODDARD, Abby; HARMER, Adele; HAVER, Katherine. Providing Aid in Insecure Environments: Trends in Policy and Operations. HPG Report 23. Londres: Overseas Development Institute, 2006.

TERRY, Fiona. Condemned to Repeat? The Paradox of Humanitarian Action. Ithaca: Cornell University Press, 2002.

THAKUR, Ramesh. The United Nations, Peace and Security: From Collective Security to the Responsibility to Protect. Cambridge: Cambridge University Press, 2006.

VALLAEYS, Anne. Médécins Sans Frontières: la biographie. Paris: Fayard, 2004.

WAAL, Alex de. Famine Crimes. Bloomington: Indiana University Press, 2001.

WALKER, Peter; RUSS, Catherine. Professionalizing the Humanitarian Sector: A Scoping Study. Relatório Comissionado pela Enhancing Learning and Research for Humanitarian Assistance, abr. 2010.

WEINLICH, Silke. Funding the UN System. In: BROWNE, S.; WEISS, T. G. (Org.). Post-2015 UN Development: Making Change Happen. Londres: Routledge, [no prelo]. 
WEISS, Thomas G. Principles, Politics, and Humanitarian Action. Ethics \& International Affairs, v. 13, n. 1, p. 1-22, 1999.

. Humanitarian Intervention: Ideas in Action. 2. ed. Cambridge: Polity Press, 2012.

. Humanitarian Business. Cambridge: Polity Press, 2013.

. Humanitarian Action, Impulse Not Imperative. In: EINSEDEL, Sebastian von; MALONE, David; STAGNO, Bruno (Org.). The United Nations Security Council: From Cold War to the $21^{\text {st }}$ Century. Boulder: Lynne Rienner, [no prelo].

; HOFFMAN, Peter J. Making Humanitarianism Work. In: CHESTERMAN, S.; IGNATIEFF, M.; THAKUR, R. (Org.). Making States Work: State Failure and the Crisis of Governance. Tóquio: UN University Press, 2005. p. 296-317.

WHEELER, Nicholas J. Saving Strangers: Humanitarian Intervention in International Society. Oxford: Oxford University Press, 2000.

WIENER, Myron. The Clash of Norms: Dilemmas in Refugee Policies. Journal of Refugee Studies, v. 11, n. 4, p. 1-21, 1998.

WILLIAMS, Phil. Transnational Criminal Organizations and International Security. Survival, v. 36, n. 1, p. 96-113, 1994.

WOOD, Adrian; APTHORPE, Raymond; BORTON, John (Org.). Evaluating International Humanitarian Action: Reflections from Practitioners. Londres: Zed, 2001.

\section{Resumo}

\section{A Cultura Humanitária Contestada em Zonas de Guerra}

A ação humanitária em zonas de guerra nunca foi fácil, porém tem se mostrado especialmente intimidadora no pós-Guerra Fria. Este ensaio começa com a cultura tradicional dominante, que servirá de parâmetro para se explorar o afastamento de uma cultura acordada de cooperação, em direção a 
uma cultura contestada de competição, fruto da militarização, da politização e da mercantilização. Esses três aspectos não são toda a verdade do projeto humanitário, mas são componentes essenciais. Conclui-se com um apelo por uma "cultura de aprendizagem", orientada para a reflexão responsável, ao invés de ser orientada para a reação rápida.

Palavras-chave: Ação Humanitária - Zonas de Guerra - Militarização Politização - Mercantilização

\section{Abstract}

\section{Humanitarianism's Contested Culture in War Zones}

Humanitarian action in war zones was never easy but has proved especially daunting in the post-Cold War era. This essay begins with the dominant traditional humanitarian culture as a metric to explore the move away from an agreed culture of cooperation to a contested one of competition as a result of militarization, politicization, and marketization. These three aspects are not the whole truth of the humanitarian project, but they are essential components. It is crucial to understand how the international humanitarian system functions if one hopes to improve its operations and attenuate, if not eliminate, the culture of competition and counter-productivity. The essay concludes with a plea for a "learning culture" oriented to responsible reflection rather than rapid reaction.

Keywords: Humanitarian Action - War Zones - Militarization Politicization - Marketization 